\title{
Hubungan Antara Pengetahuan Dan Sikap Dengan Praktik Penggunaan APD Pada Petani Pengguna Pestisida
}

\section{The Relationship Between Knowledge And Attitude With The Practice Of Using Personal Protective Equipment For Farmers Using Pesticides}

\author{
Heni Fa'riatul Aeni *), Rina Nurfadillah \\ STIKes Cirebon \\ Jl.Brigjen Dharsono No 12B (By Pass) Cirebon
}

Submitted : 19-07-2018

Reviewed : 23 -08-2018

Accepted : $28-08-2018$

\begin{abstract}
ABSTRAK
Pertanian memiliki kontribusi baik terhadap perekonomian maupun terhadap pemenuhan kebutuhan pokok masyarakat. Perkiraan World Health Organization (WHO) pada tahun 2009 terjadi sekitar 600.000 kasus dan 60.000 kematian. Hasil penelitian Pesticide Action Network Asia and the Pasific (PANAP) pada Agustus-Oktober 2008 menunjukan bahwa dari 100 responden 6 orang terdiri dari 2 orang perempuan dan 4 orang laki-laki mengalami gangguan kesehatan. Tujuan penelitian ini adalah untuk mengetahui hubungan pengetahuan dan sikap dengan praktik penggunaan APD pada petani pengguna pestisida di Desa Sigambir Kecamatan Brebes Kabupaten Brebes Tahun 2018. Rancangan penelitian ini menggunakan pendekatan kuantitatif dengan desain cross sectional. Variabel yang diteliti yaitu pengetahuan, sikap dan praktik penggunaan Alat Pelindung Diri (APD). Populasi penelitian ini adalah petani pengguna pestisida di Desa Sigambir Kecamatan Brebes Kabupaten Brebes sebanyak 316 responden dengan jumlah sampel sebanyak 76 diambil menggunakan metode simpel random sampling, yaitu pengambilan sampel secara random atau acak. Data analisis secara statistik yang digunakan adalah Chi Square dengan tingkat kepercayaan 5\% $(0,05)$.

Dari 76 responden yang diteliti sebanyak $51,3 \%$ responden memiliki pengetahuan kurang baik, $51,3 \%$ responden memiliki sikap negatif dan 98,7\% responden tidak lengkap dalam penggunaan APD. Hasil uji statistik didapatkan bahwa tidak ada hubungan antara pengetahuan $(\mathrm{P}=0,487)$ dan sikap $(\mathrm{P}=0,487)$ dengan praktik penggunaan Alat Pelindung Diri (APD) pada petani pengguna pestisida di Desa Sigambir Kecamatan Brebes Kabupaten Brebes tahun 2018. Petani diharapkan lebih meningkatkan pengetahuan dan kesadaran akan pentingnya penggunaan APD secara lengkap serta menjadikan sebagai budaya untuk petani dalam penggunaan APD saat melakukan penyemprotan dan bagi Puskesmas perlu dilakukan sosialisasi mengenai keselamatan dan kesehatan kerja petani pengguna pestisida khususnya mengenai pentingnya penggunaan APD secara lengkap terkait dengan program kesehatan kerja pada puskesmas.
\end{abstract}

Kata kunci : Pengetahuan, Sikap dan Praktik Penggunaan Alat Pelindung Diri (APD) 


\begin{abstract}
Agriculture has a contribution both to the economy and to the fulfillment of basic needs of society. World Health Organization (WHO) estimates in 2009 occurred around 600.000 cases and 60.000 deaths. The research results of Pesticide Action Network Asia and the Pasific (PANAP) from August to October 2008 showed that from 100 respondents 6 people consisted of 2 women and 4 men suffered health problems. The purpose of this study was to determine the relationship of knowledge and attitude with the practice of using PPE on the farmers of pesticide users in Sigambir Village Brebes District Brebes Year 2018. The design of this study using a quantitative approach studied were knowledge, attitude and practice of using Personal Protective Equipment (PPE). The population of this research is farmer of pesticide user in Sigambir Village Brebes Sub-district og Brebes of Brebes Regency with 316 respondents with 76 samples taken using simple random sampling method, that that is random or random sampling. Statistical data were analyzed using Chi Square with 5\% confidence level $(0,05)$. Of the 76 respondents surveyed were $51,3 \%$ of respondents had poop knowledge, $51,3 \%$ of respondents had negative attitude and $98,7 \%$ of respondents did not Complete in the use of PPE. The result of statistical test shows that there is no correlation between knowledge $(\mathrm{P} 0,487)$ and attitude ( $\mathrm{P}$ 0,487) with practice of using Personal Protective Equipment (PPE) on farmer or pesticide user in Sigambir Village Brebes Subdistrict of Brebes Regency 2018. Farmers are expected to increase knowledge and awreness of the importance of the useof PPE as well as to make culture for farmers in the use of PPE when spraying and for the Puskesmas need to be socialized about the safety and health of farmers of pesticides users, especially about the importance of the use of PPE in full Occupational to health programs work at puskesmas.
\end{abstract}

\title{
Keywords : Knowledge, Attitudes and Practice of Using Personal Protective Equipment $(\boldsymbol{P P E})$
}

\section{Penulis korespondensi:}

Heni Fa'riatul Aeni

STIKes Cirebon

Jl.Brigjen Dharsono No 12B (By Pass) Cirebon

Email: henifariatulaeni80@gmail.com; Hp 085321338538

\section{PENDAHULUAN}

Kesehatan kerja harus mengarahkan pada promosi dan pemeliharaan derajat kesehatan yang paling tinggi secara fisik, mental dan sosial yang baik dari para tenaga kerja dalam semua jenis pekerjaan dan jabatan; pencegahan diantara para tenaga kerja dari gangguan kesehatan yang disebabkan oleh kondisi kerja; perlindungan para tenaga kerja dalam pekerjaannya dari risiko sebagai akibat faktor-faktor yang merugikan kesehatan; penempatan dan pemeliharaan tenaga kerja dalam lingkungan kerja yang diadaptasi pada kemampuan fisiologis dan psikologis; dan penyesuaian pekerja pada manusia dan setiap orang pada pekerjaannya (Soedirman dkk, 2014).

Dalam hal ini, konsep budaya kerja dalam perspektif kesehatan kerja dimaksudkan untuk memberi pengertian tentang berbagai aspek penanganan dan pencegahan penyakit akibat kerja sebagai refleksi sistem tata nilai (Soedirman dkk, 2014).

Saat ini terdapat ribuan senyawa kimia dan campuran yang kebanyakan berbahaya yang secara teknik dapat dikendalikan. Kebanyakan kecelakaan adalah akibat mengabaikan sifat-sifat bahan kimia yang terkait dengan proses (Cahyono A.B., 2004). Chemical Safety 
atau Keselamatan bahan kimia adalah upaya perlindungan kesehatan manusia dan atau pekerja, fasilitas dan instalasi serta lingkungan di setiap kegiatan pada simpul daur hidup bahan kimia dari penyalahgunaan bahan kimia dan penggunaan bahan kimia yang salah (Anonim $\left.{ }^{1}, 2018\right)$.

Bahan kimia banyak digunakan dalam lingkungan industri, yang dapat dibagi dalam dua kelompok besar yaitu satu industri kimia, yaitu industri yang mengolah dan menghasilkan bahan-bahan kimia, diantaranya industri pupuk, asam sulfat, soda, bahan peledak, pestisida, cat, deterjen, dan lain-lain. Industri kimia dapat diberi batasan sebagai industri yang ditandai dengan penggunaan proses-proses yang bertalian dengan perubahan kimiawi atau fisik dalam sifat-sifat bahan tersebut dan khususnya pada bagian kimiawi dan komposisi suatu zat. Dua Industri Pengguna Bahan Kimia, yaitu industri yang menggunakan bahan kimia sebagai bahan pembantu proses, diantaranya industri tekstil, kulit, kertas, pelapisan listrik, pengolahan logam, obat-obatan dan lain-lain (Cahyono A.B., 2004).

Dalam lingkungan kerja tersebut, banyak bahan kimia yang terpakai tiap harinya sehingga para pekerja terpapar bahaya dari bahan-bahan kimia itu. Bahaya tersebut terkadang meningkat dalam kondisi tertentu mengingat sifat bahan-bahan kimia itu, seperti mudah terbakar, beracun, dan sebagainya. Dengan demikian, jelas bahwa bekerja dengan bahan-bahan kimia mengandung risiko bahaya, baik dalam proses, penyimpanan, transportasi, distribusi, dan penggunaannya. Akan tetapi, betapapun besarnya bahaya bahanbahan kimia tersebut, penanganan yang benar akan dapat mengurangi atau menghilangkan risiko bahaya yang diakibatkannya (Cahyono A.B., 2004).

Pertanian memiliki kontribusi baik terhadap perekonomian maupun terhadap pemenuhan kebutuhan pokok masyarakat. Meningkatnya jumlah penduduk membuat kebutuhan pangan semakin meningkat hasil tanaman, salah satunya dengan meminimalkan hama yang menyerang tanaman dengan menggunakan obat kimia pembasmi hama tanaman seperti pestisida, karena tanaman yang sudah terserang hama akan berdampak pada kerusakan tanaman yang berakibat turunnya nilai jual bahkan sampai mangalami gagal panen. Walaupun memberi dampak baik akan hasil tanaman, pestisida juga dapat memberikan dampak buruk (Shobib, M.N., 2013).

Setiap hari ribuan petani dan para pekerja di sektor pertanian teracuni oleh pestisida dan setiap tahun diperkirakan jutaan orang yang terlibat di pertanian menderita keracunan akibat pestisida. Perkiraan World Health Organization (WHO) pada tahun 2009 terjadi sekitar 600.000 kasus dan 60.000 kematian terjadi di India dan yang paling rentan adalah anak-anak, perempuan, pekerja di sektor informal dan petani miskin. Di Bangladesh, pada 2008, keracunan pestisida paling tinggi menyebabkan kematian. Di Kamboja, setidaknya $88 \%$ petani mengalami dampak akut keracunan pestisida, di China, antara 53.000 sampai 10.000 mengalami dampak yang sangat berbahaya seperti kanker, cacat, mandul, dan hepatitis setiap tahunnya (Purwati A., 2010

Sebagai Negara agraris, penggunaan pestisida di Indonesia cukup tinggi. Pada tahun 2006 tercatat sekitar 1.336 formulasi dan 402 bahan aktif pestisida telah didaftarkan untuk mengendalikan hama di berbagai bidang komoditi. Hasil penelitian Pesticide Action Network Asia and the Pasific (PANAP) tentang bahaya pestisida di Wonosobo, Jawa Tengah sebagai bagian pemantauannya di kawasan Asia, pada Agustus-Oktober 2008 menunjukan bahwa dari 100 responden 6 orang terdiri dari 2 orang perempuan dan 4 orang laki-laki mengalami gangguan kesehatan (Purwati A., 2010).

Pengetahuan adalah hasil penginderaan manusia, atau hasil tahu seseorang terhadap objek melalui indera yang dimilikinya (mata, hidung, telinga, dan sebagainya). Dengan sendirinya pada waktu penginderaan sampai menghasilkan pengetahuan tersebut sangat dipengaruhi oleh intensitas perhatian dan persepsi terhadap objek. Sikap adalah juga respons tertutup seseorang terhadap stimulus atau objek tertentu, yang sudah melibatkan faktor pendapat dan emosi yang bersangkutan (senang-tidak senang, setuju-tidak setuju, baik-tidak baik, dan sebaginya). Menurut Newcomb yang dikutip oleh Notoatmodjo (1997) bahwa sikap merupakan kesiapan/kesediaan seseorang untuk bertindak sebagai objek di lingkungan tertentu sebagai suatu penghayatan terhadap objek (Notoatmodjo S., 2010). 
Masih banyak para pengguna bahan kimia jenis pestisida khususnya para petani yang sangat minim pengetahuan tentang bagaimana dampak bahan kimia dalam jangka panjang dan sikap para petani atau pengguna pestisida yang tidak mengetahui bagaimana penggunaan alat pelindung diri (APD) pada saat pencampuran dan penyemprotan pestisida.

Hasil penelitian yang dilakukan oleh Muhammad Nur Shobib pada tahun 2013, dalam pengetahuan petani tentang pernyataan penggunaan Alat Pelindung Diri (APD) dapat mencegah terjadinya keracunan saat penyemprotan pestisida sebesar 96,2\% responden menjawab benar. Sikap petani dalam pernyataan saat berinteraksi dengan pestisida harus menggunakan Alat Pelindung Diri (APD) secara lengkap dimana diperoleh sebanyak 80,8\% petani setuju, sikap petani tentang pemakaian Alat Pelindung Diri (APD) lebih rendah dari pada pengetahuan. Hasil pengetahuan diperoleh $\rho$ value $=0,658$ dan pada sikap $\rho$ value $=$ 0,902 , karena $\rho$ value $>0,05$ maka, Ho diterima sehingga dapat disimpulkan bahwa tidak ada hubungan antara pengetahuan dan sikap terhadap praktik penggunaan APD pada petani pengguna pestisida Desa Curut Kec. Penawangan Kab. Grobogan (Shobib, M.N., 2013).

Berdasarkan penelitian Vondra Anggi Saputro diperoleh data responden yang memiliki pengetahuan tidak baik dan tidak menggunakan APD sebanyak 17 orang $(81,0 \%)$ dan yang menggunakan APD sebanyak 4 orang $(19,0 \%)$. Sementara responden yang memiliki pengetahuan baik dan menggunakan APD sebanyak 13 orang $(68,4 \%)$ dan yang tidak menggunakan APD sebanyak 6 orang $(31,8 \%)$. Hal tersebut menunjukkan bahwa proporsi responden yang memiliki pengetahuan tidak baik dan tidak menggunakan APD lebih tinggi dibandingkan dengan responden yang memiliki pengetahuan baik dan menggunakan APD. Hasil ini masih konsisten dengan penelitian Sihombing (2014), bahwa ada hubungan antara pengetahuan dengan penggunaan alat pelindung diri dengan nilai $(\mathrm{p}=$ 0,004). Hasil penelitian hubungan antara sikap dengan penggunaan APD, dengan hasil responden yang memiliki sikap negatif dan tidak menggunakan APD sebanyak 17 orang $(77,3 \%)$ dan yang menggunakan APD sebanyak 5 orang $(22,7 \%)$, sedangkan responden yang memiliki sikap positif dan menggunakan APD sebanyak 12 orang $(66,7 \%)$ dan yang tidak menggunakan APD sebanyak 6 orang $(33,3 \%)$. Berdasarkan hasil uji analisis statistik disimpulkan bahwa ada hubungan antara sikap dengan penggunaan APD dengan nilai $(\mathrm{p}=$ 0,005<0,05) (Saputro V.A., 2015).

Berbeda dengan hasil penelitian yang dilakukan oleh Asriyani (2011) didapatkan $\mathrm{P}=$ 0,002 ( $\mathrm{P}$ value $<0,05$ ) sehingga menunjukkan ada hubungan antara motivasi dan perilaku penggunaan APD. Kemungkinan bias pada variabel ini adalah motivasi pekerja dalam menggunakan APD tidak hanya dipengaruhi dari kenyamanan dan keamanan dari APD yang digunakan melainkan juga ada ketentuan dan peraturan dari pemilik usaha untuk menggunakan APD ditempat kerja sehingga tidak diketahui faktor pendukung mana yang paling kuat hubungan dengan perilaku penggunaan APD. Hasil tersebut tidak sesuai dengan pendapat Green dalam Notoadmojo yang menyatakan motivasi merupakan salah satu faktor berpengaruh (predisposing factors) yang mendorong atau menghambat individu untuk berperilaku (dalam hal ini penggunaan APD) (Notoatmodjo S., 2012).

Kabupaten Brebes adalah salah satu Kabupaten di Provinsi Jawa Tengah, Indonesia. Luas wilayahnya $1.902,37 \mathrm{~km}^{2}$ dan jumlah penduduknya sekitar 1.732 .719 jiwa pada dath tahun 2010 dengan ibukota yang terletak di Kecamatan Brebes. Brebes merupakan kabupaten dengan jumlah penduduk paling banyak di Jawa Tengah, dan paling luas di Jawa Tengah ke-2 setelah Kabupaten Cilacap. Sektor pertanian merupakan sektor yang dominan di Brebes. Dari sekitar 1,7 juta penduduk Brebes, sekitar 70 persen bekerja pada sektor pertanian. Sektor ini menyumbang 53 persen Produk Domestik Regional Bruto (PDRB) Kabupaten Brebes, yang 50 persen dari pertanian bawang merah. Desa Sigambir adalah salah satu Desa yang terletak di Kecamatan Brebes dengan jumlah penduduk 3.509 jiwa dan lebih dari 50 persen penduduknya bekerja sebagai petani $\left(\right.$ Anonim $^{2}$, 2018).

Berdasarkan hasil studi pendahuluan yang telah dilakukan terhadap 15 petani pengguna pestisida di Desa Sigambir pada tanggal 8 Mei 2018, hasil observasi peneliti didapatkan bahwa 8 petani memakai baju lengan panjang dan 7 (46,67\%) petani tidak memakai baju lengan panjang, 6 petani memakai celana panjang dan $9(60 \%)$ petani tidak 
memakai celana panjang, 2 petani memakai alat penutup hidung dan mulut (masker) dan 13 $(86,67 \%)$ petani tidak memakai alat penutup hidung dan mulut (masker), 4 petani memakai sarung tangan dan $11(73,33 \%)$ petani tidak memakai sarung tangan dan 14 petani memakai topi dan hanya $1(6,67 \%)$ petani yang tidak memakai topi. Dari total 15 petani tersebut juga diketahui 10 diantaranya sering mengeluh sakit kepala atau pusing pada saat penyampuran pestisida. Tidak sedikit juga yang sering mengalami alergi karena berinteraksi langsung dengan pestisida tanpa menggunakan Alat Pelindung Diri (APD) berupa sarung tangan. Dari 15 petani ada 2 petani yang pernah mengalami keracunan pada saat bekerja dan berinteraksi langsung dengan pestisida.

Dari uraian diatas penulis tertarik untuk melakukan penelitian lebih lanjut mengenai hubungan antara pengetahuan dan sikan dengan praktik penggunaan Alat Pelindung Diri (APD) pada petani pengguna pestisida di Desa Sigambir Kecamatan Brebes Kabupaten Brebes Tahun 2018.

\section{METODE PENELITIAN}

Penelitian ini merupakan penelitian kuantitatif menggunakan metode survei analitik dengan pendekatan cross sectional (potong lintang), karena pada penelitian ini variabel independen dan dependen akan diamati pada waktu (periode) yang sama (Notoatmodjo S., 2014).

Variabel bebas pada penelitian ini adalah pengetahuan dan sikap sedangkan variabel terikat pada penelitian ini adalah praktik penggunaan APD pada petani. Populasi dalam penelitian ini adalah seluruh petani pengguna pestisida yang tergabung dalam kelompok tani di Desa Sigambir Kecamatan Brebes Kabupaten Brebes yang berjumlah 316 petani. Sampel dalam penelitian ini adalah petani yang bertempat tinggal di Desa Sigambir Kecamatan Kabupaten Brebes yang memenuhi kriteria inklusi dan eksklusi.

Untuk menentukan besarnya sampel minimal yang terdapat dalam populasi yaitu dengan rumus:

$$
\mathrm{n}=\frac{\mathrm{N}}{\mathrm{N} \cdot \mathrm{d}^{2}+1}
$$

$$
\begin{aligned}
& \text { Keterangan: } \\
& \mathrm{n}=\text { Jumlah sampel } \\
& \mathrm{N}=\text { Jumlah populasi } \\
& \mathrm{d}^{2}=\text { Presisi yang ditetapkan } 90 \% \text { atau } 0,1 \\
& \mathrm{n}=\frac{316}{316.0,1^{2}+1} \\
& \mathrm{n}=75,96 \text { (dibulatkan menjadi } 76)
\end{aligned}
$$

Dari hasil perhitungan rumus di atas, maka sampel minimal yang di ambil sebanyak 76 sampel. Maka pengambilan sampel selanjutnya dengan menggunakan simple random sampling, yaitu pengambilan sampel secara random atau acak dan dengan mengundi anggota populasi (lottery technique) atau teknik undian. berikut:

Sampel dalam penelitian tersebut harus memenuhi kriteria inklusi dan eksklusi sebagai

1. Kriteria Inklusi

Kriteria inklusi sampel dalam penelitian ini adalah:

1) Petani pengguna pestisida yang bertempat tinggal di Desa Sigambir

2) Petani yang berpendidikan minimal tamat $\mathrm{SD}$ (pengetahuan lebih tinggi)

3) Dapat berkomunikasi dengan baik

4) Bersedia diwawancarai

2. Kriteria Eklusi

Kriteria eksklusi sampel dalam penelitian ini adalah: 
1) Petani pengguna pestisida yang tidak bertempat tinggal di Desa Sigambir

2) Tidak dapat berkomunikasi dengan baik

3) Tidak bersedia diwawancarai

\begin{abstract}
Alat dan Bahan
Instrumen penelitian yang digunakan untuk mengetahui pengetahuan dan sikap adalah kuesioner sedangkan untuk mengetahui praktik penggunaan Alat Pelindung Diri (APD) adalah lembar check list.

Data primer yang dikumpulkan dalam penelitian ini meliputi data tentang pengetahuan petani tentang APD (pengertian, manfaat, dan akibat tidak menggunakan APD), Sikap petani tentang APD, dan penggunaan APD pada petani. Data sekunder dalam penelitian ini adalah data monografi Desa Sigambir Kecamatan Brebes Kabupaten Brebes tahun 2018.

Alat ukur (Kuesioner dan Lembar Chek List) atau instrumen yang digunakan dalam penelitian ini tidak dilakukan uji coba kuesioner, baik uji validitas maupun realibilitas, karena kuesioner yang digunakan oleh peneliti mengadopsi dari Faris Khamdani Universitas Negeri Semarang Tahun 2009.

\section{Jalannya Penelitian}

1. Permohonan ijin kepada Kepala Desa

2. Pemberian dan pengisian informed consent kepada responden

3. Pengisian kuesioner dengan cara wawancara kepada responden

4. Pengolahan data dimulai dari : Editing, Coding, Entry Data, Cleaning

5. Melakukan analisa data univariat dan bivariat
\end{abstract}

\title{
Analisis Data
}

Proses pengolahan data melalui tahap-tahap berikut ini:

1. Editing

Secara umum editing adalah merupakan kegiatan untuk pengecekan dan perbaikan isian formulir atau kuesioner.

2. Coding

Setelah semua kuesioner diedit atau disunting, selanjutnya dilakukan pengkodean atau coding, yakni mengubah data berbentuk kalimat atau huruf menjadi data angka atau bilangan. Koding atau pemberian kode ini sangat berguna dalam memasukan data (data entry).

3. Memasukan Data (Data Entry) atau Procesing

Jawaban dari masing-masing responden yang dalam bentuk kode (angka atau huruf) dimasukan kedalam program atau software komputer. Program yang digunakan untuk entry data penelitian adalah SPSS.

4. Pembersihan Data (Cleanning)

Apabila semua data dari setiap sumber data atau responden selesai dimasukan, perlu dicek kembali untuk melihat kemungkinan-kemungkinan adanya kesalahan-kesalahan kode, ketidaklengkapan, dan sebagainya, kemudian dilakukan pembetulan atau koreksi. Proses ini disebut pembersihan data (data cleanning) (Notoatmodjo S., 2014).

\section{Analisis Univariat (Analisis Deskriptif)}

Analisis yang dilakukan disajikan data bentuk distribusi frekuensi dan presentase dari masing-masing variabel bebas yaitu pengetahuan dan sikap serta variabel terikat praktik penggunaan Alat Pelindung Diri (APD). 


\section{Analisis Bivariat}

Apabila telah dilakukan analisis univariat tersebut diatas, hasilnya akan diketahui karakteristik atau distribusi setiap variabel, dan dapat dilanjutkan analisis bivariat. Analisis bivariat yang dilakukan terhadap dua variabel yang diduga berhubungan atau berkorelasi (Notoatmodjo S., 2014). Analisis bivariat pada penelitian ini untuk mengetahui hubungan pengetahuan dengan praktik penggunaan Alat Pelindung Diri (APD) dan hubungan sikap dengan praktik penggunaan Alat Pelindung Diri (APD).

Uji statistik yang digunakan penelitian ini yaitu dengan menggunakan Chi Square (X2) adalah salah satu uji statistic no-parametik (distibusi dimana besaran-besaran populasi tidak diketahui) yang cukup sering digunakan dalam penelitian yang menggunakan dua variabel, dimana skala data kedua variabel adalah nominal atau untuk menguji perbedaan dua atau lebih proporsi sampel (Anonim ${ }^{3}$, 2013). Maka akan menghasilkan keputusan sebagai berikut:

1. Jika $\mathrm{P}$ (value) $<0,05=\mathrm{H}_{0}$ ditolak berarti ada hubungan antara pengetahuan dan sikap dengan praktik penggunaan APD pada petani pengguna pestisida.

2. Jika $\mathrm{P}($ value $)>0,05=\mathrm{H}_{0}$ diterima berarti tidak ada hubungan antara pengetahuan dan sikap dengan praktik penggunaan APD pada petani pengguna pestisida.

Lokasi penelitian dilakukan di Desa Sigambir Kecamatan Brebes Kabupaten Brebes yang dilakukan pada bulan April-Juli 2018.

Etika dalam penelitian menunjukan pada prinsip-prinsip etis yang diterapkan dalam kegiatan penelitian, dari proposal penelitian sampai dengan publikasi hasil penelitian. Secara garis besar, dalam melaksanakan sebuah penelitian ada empat prinsip yang harus dipegang teguh, yakni:

1. Menghormati harkat dan martabat manusia (respect for human dignity).

2. Menghormati privasi dan kerahasiaan subjek penelitian (respect for privacy and confidentiality).

3. Keadilan dan inklusivitas/keterbukaan (respect for justice an inclusiveness).

4. Memperhitungkan manfaat dan kerugian yang ditimbulkan (balancing harms and benefitsI) (Notoatmodjo S., 2014).

\section{HASIL DAN PEMBAHASAN}

\section{Analisis Univariat}

Berdasarkan tabel I dapat dilihat bahwa dari 76 responden yang diteliti sebanyak $51,3 \%$ responden memiliki pengetahuan kurang baik tentang Alat Pelindung Diri (APD), $51,3 \%$ responden memiliki sikap negatif dan $98,7 \%$ responden tidak lengkap dalam penggunaan Alat Pelindung Diri (APD)

Tabel I Distribusi Frekuensi Pengetahuan, Sikap dan Praktik Penggunaan Alat Pelindung Diri (APD) pada Petani Pengguna Pestisida di Desa Sigambir Kecamatan Brebes Kabupaten Brebes Tahun 2018

\begin{tabular}{|c|c|c|}
\hline Pengetahuan & Frekuensi & Presentase $(\%)$ \\
\hline Kurang Baik & 39 & 51,3 \\
\hline Baik & 37 & 48,7 \\
\hline Jumlah & 76 & 100,0 \\
\hline Sikap & Frekuensi & Presentasi $(\%)$ \\
\hline Negatif & 39 & 51,3 \\
\hline Positif & 37 & 48,7 \\
\hline Jumlah & 76 & 100,0 \\
\hline $\begin{array}{lll}\text { Praktik Penggunaan } & \text { Alat } \\
\text { Pelindung Diri (APD) } & \\
\end{array}$ & Frekuensi & Presentasi $(\%)$ \\
\hline Tidak Lengkap & 75 & 98,7 \\
\hline Lengkap & 1 & 1,3 \\
\hline Jumlah & 76 & 100,0 \\
\hline
\end{tabular}

Hubungan Antara Pengetahuan Dan Sikap Dengan Praktik Penggunaan ..... (Heni Fa'riatul, dkk) 
Analisis Bivariat

1. Hubungan Pengetahuan dengan Praktik Penggunaan Alat Pelindung Diri (APD)

Tabel II Hubungan Pengetahuan dengan Praktik Penggunaan Alat Pelindung Diri (APD) pada Petani Pengguna Pestisida di Desa Sigambir Kecamatan Brebes Kabupaten Brebes Tahun 2018

\begin{tabular}{|c|c|c|c|c|c|c|c|c|}
\hline \multirow{3}{*}{ No } & \multirow{3}{*}{$\begin{array}{c}\text { Pengetahuan } \\
\text { Petani }\end{array}$} & \multicolumn{4}{|c|}{ Praktik Penggunaan APD } & \multirow{2}{*}{\multicolumn{2}{|c|}{ Total }} & \multirow{3}{*}{$\begin{array}{c}\mathbf{P} \\
\text { value }\end{array}$} \\
\hline & & \multicolumn{2}{|c|}{ Tidak Lengkap } & \multicolumn{2}{|c|}{ Lengkap } & & & \\
\hline & & $\mathbf{n}$ & $\%$ & $\mathbf{n}$ & $\%$ & $\mathbf{n}$ & $\%$ & \\
\hline 1 & Kurang Baik & 39 & 100,0 & 0 & 0,0 & 39 & 100,0 & \multirow{3}{*}{0,487} \\
\hline 2 & Baik & 36 & 97,3 & 1 & 2,7 & 37 & 100,0 & \\
\hline & Total & 75 & 98,7 & 1 & 1,3 & 76 & 100,0 & \\
\hline
\end{tabular}

Pada tabel II hasil penelitian menunjukan bahwa responden yang memiliki pengetahuan kurang dan tidak lengkap dalam praktik penggunaan Alat Pelindung Diri (APD) sebesar $100,0 \%$ dan responden yang memiliki pengetahuan baik dan tidak lengkap dalam praktik penggunaan Alat Pelindung Diri (APD) sebesar 97,3\%.

Berdasarkan hasil uji statistik menggunakan chi square dengan taraf kepercayaan $5 \%$ $(0,05)$ didapatkan nilai $\rho$ value $=0,487$ ( $\rho$ value $>0,05)$ maka $\mathrm{H}_{0}$ diterima sehingga dapat disimpulkan bahwa tidak ada hubungan antara pengetahuan dengan praktik penggunaan Alat Pelindung Diri (APD) pada petani pengguna pestisida di Desa Sigambir Kecamatan Brebes Kabupaten Brebes Tahun 2018.

\section{Hubungan Sikap dengan Praktik Penggunaan Alat Pelindung Diri (APD)}

Pada tabel III hasil penelitian menunjukan responden yang memiliki sikap negatif dan tidak lengkap dalam praktik penggunaan Alat Pelindung Diri (APD) sebesar 100,0\% dan responden yang memiliki sikap positif dan tidak lengkap dalam praktik penggunaan Alat Pelindung Diri (APD) sebesar 97,3\%.

Berdasarkan hasil uji statistik menggunakan chi square dengan taraf kepercayaan 5\% $(0,05)$ didapatkan nilai $\rho$ value $=0,487$ ( $\rho$ value $>0,05)$ maka $\mathrm{H}_{0}$ diterima sehingga dapat disimpulkan bahwa tidak ada hubungan antara sikap dengan praktik penggunaan Alat Pelindung Diri (APD) pada petani pengguna pestisida di Desa Sigambir Kecamatan Brebes Kabupaten Brebes Tahun 2018.

Tabel III Hubungan Sikap dengan Praktik Penggunaan Alat Pelindung Diri (APD) pada Petani Pengguna Pestisida di Desa Sigambir Kecamatan Brebes Kabupaten Brebes Tahun 2018

\begin{tabular}{|c|c|c|c|c|c|c|c|c|}
\hline \multirow{3}{*}{ No } & \multirow{3}{*}{ Sikap Petani } & \multicolumn{4}{|c|}{ Praktik Penggunaan APD } & & & \multirow{3}{*}{$\underset{\text { value }}{\mathrm{P}}$} \\
\hline & & \multicolumn{2}{|c|}{$\begin{array}{c}\text { Tidak } \\
\text { Lengkap }\end{array}$} & \multicolumn{2}{|c|}{ Lengkap } & \multicolumn{2}{|c|}{ Total } & \\
\hline & & $\mathbf{n}$ & $\%$ & $\mathbf{n}$ & $\%$ & $\mathbf{n}$ & $\%$ & \\
\hline 1 & Negatif & 39 & $\begin{array}{c}100, \\
0\end{array}$ & 0 & 0,0 & 39 & 100,0 & 0.487 \\
\hline 2 & Positif & 36 & 97,3 & 1 & 2,7 & 37 & 100,0 & \\
\hline & Total & 75 & 98,7 & 1 & 1,3 & 76 & 100,0 & \\
\hline
\end{tabular}

\section{Keterbatasan Penelitian}

Penelitian tentang Hubungan antara Pengetahuan dan Sikap dengan Praktik Penggunaan Alat Pelindung Diri (APD) di Desa Sigambir Kecamatan Brebes Kabupaten Brebes Tahun 2018 ini tidak lepas dari keterbatasan penelitian, batasan penelitian ini adalah :

1. Keterbatasan waktu pada saat wawancara menjadikan responden menjawab dengan tidak serius. 
2. Responden kurang memahami pertanyaan dalam kuesioner karena rendahnya pengetahuan tentang Alat Pelindung Diri (APD), manfaat Alat Pelindung Diri (APD) dan dampak apabila tidak memakai Alat Pelindung Diri (APD) sehingga dapat mempengaruhi hasil penelitian atau bias.

3. Masih ada beberapa jawaban yang diberikan tidak sesuai dengan kondisi yang ada. Sehingga jawaban yang diperoleh tidak sesuai hasil observasi.

Terlepas dari beberapa kelemahan tersebut, penelitian berusaha semaksimal mungkin untuk melaksanakan penelitian ini dengan sebaik-baiknya.

\section{Pembahasan}

\section{Analisis Univariat}

Hasil penelitian menunjukan bahwa sebanyak $51,3 \%$ responden memiliki pengetahuan kurang baik tentang Alat Pelindung Diri (APD), 51,3\% responden memiliki sikap negatif dan 98,7\% responden tidak lengkap dalam penggunaan Alat Pelindung Diri (APD).

Lawrence Green menjelaskan bahwa perilaku itu dilatar belakangi atau dipengaruhi oleh tiga faktor pokok yakni faktor predisposisi (predisposing factor), faktor yang mendukung (enabling factor), dan faktor yang memperkuat atau mendorong atau penguat (reinforcing factor) (Notoatmodjo S., 2010).

Pengukuran pengetahuan dalam penelitian ini dilakukan pada petani yakni dengan mengukur pengetahuan APD tentang pengertian APD, manfaat APD dan akibat tidak menggunakan APD yang diperoleh melalui jawaban atas pertanyaan responden pada kuesioner. Berdasarkan hasil 51,3\% reponden memiliki pengetahuan yang kurang baik tidak berbeda jauh dengan hasil sikap yaitu 52,6\% responden memiliki sikap negatif.

Ada banyak faktor yang mempengaruhi hasil pengetahuan yang kurang baik dan sikap yang negatif. Yang pertama yaitu pendidikan, semakin tinggi pendidikan seseorang maka makin mudah pula bagi mereka untuk menerima informasi dan pada akhirnya makin banyak pengetahuan yang mereka miliki. Kedua informasi, kemudahan seseorang untuk memperoleh informasi dapat membantu mempercepat seseorang untuk memperoleh pengetahuan yang baru (Notoatmodjo S., 2010). Dari 76 responden yang diteliti sebagian besar memiliki pendidikan yang rendah (SD). Banyaknya informasi dari luar juga dapat mempengaruhi pengetahuan dari seseorang. Kurangnya informasi yang diperoleh oleh responden menjadi salah satu faktor kurang baiknya pengetahuan responden.

Sikap merupakan predisposisi untuk melakukan atau tidak melakukan suatu perilaku tertentu, sikap lebih suatu proses kesadaran yang sifatnya individual. Sikap yang positif akan memicu seseorang untuk melakukan suatu tindakan. Menurut Allport (1954) bahwa sikap mempunyai beberapa komponen, salah satunya kepercayaan (keyakinan), Responden tidak percaya atau tidak meyakini bahwa menggunakan Alat Pelindung Diri (APD) pada saat bekerja akan terjadi kecelakaan kerja atau mengakibatkan keracunan dan alergi yang ditimbulkan oleh pestisida.

\section{Analisis Bivariat}

\section{Hubungan Pengetahuan dengan Praktik Penggunaan Alat Pelindung Diri (APD)}

Hasil penelitian uji statistik menggunakan chi square dengan taraf kepercayaan $5 \%(0,05)$ didapatkan nilai $\rho$ value $=0,487$ ( $\rho$ value < 0,05$)$ maka $\mathrm{H}_{0}$ diterima sehingga dapat disimpulkan bahwa tidak ada hubungan antara pengetahuan dengan praktik penggunaan Alat Pelindung Diri (APD) pada petani pengguna pestisida di Desa Sigambir Kecamatan Brebes Kabupaten Brebes Tahun 2018.

Hasil penelitian ini sejalan dengan hasil penelitian yang dilakukan Muhammad Nur Sohib dengan judul hubungan antara pengetahuan dan sikap dengan praktik pemakaian Alat Pelindung Diri (APD) pada petani pengguna pestisida di Desa Curut Kecamatan Penawangan Kabupaten Grobogan tahun 2013 yang menyatakan tidak ada hubungan antara pengetahuan terhadap praktik pemakaian APD pada petani pengguna pestisida dengan nilai $\rho$ value $=0,658$ (Shobib, M.N., 2013). 
Berbeda dengan hasil penelitian Faris Khamdani dengan judul hubungan antara pengetahuan dan sikap dengan pemakaian Alat Pelindung Diri (APD) pestisida semprot pada petani di Desa Angkatan Kidul Pati tahun 2009 yang menyatakan ada hubungan antara pengetahuan dengan pemakaian Alat Pelindung Diri (APD) pestisida semprot pada petani dengan nilai $\rho$ value $=0,001$ (Khamdani, F., 2009).

Pengetahuan adalah hasil "tahu" dan ini terjadi setelah orang melakukan penginderaan terhadap suatu objek tertentu. Penginderaan terjadi melalui panca indera manusia, yakni: indera penglihatan, pendengaran, penciuman, rasa dan raba (Notoatmodjo S., 2010).

Faktor penentu atau determinan perilaku manusia sulit untuk dibatasi karena perilaku merupakan resultan dari beberapa faktor, baik internal maupun eksternal (lingkungan), secara lebih terinci, perilaku manusia sebenarnya merupakan refleksi dari berbagai gejala kejiwaan, seperti pengetahuan, keinginan, kehendak, minat, motivasi, persepsi, sikap dan sebagainya. Perilaku atau praktik petani dalam penggunaan APD dipengaruhi banyak faktor, walaupun pengetahuan petani mengerti saat berinteraksi dengan pestisida, akan tetapi dalam praktiknya bisa saja tidak sesuai. Hasil penelitian menunjukan bahwa responden yang berpendidikan SD ada $51(67,1 \%)$ responden, karena adanya faktor pendidikan dan informasi yang mempengaruhi responden, faktor lain yang mungkin berpengaruh terhadap perubahan atau pembentuk perilaku adalah faktor pendukung (enabling factor) dan faktor penguat (reinforcing factor) seperti dari kurangnya ketersediaan APD, kenyamanan, musim dan cuaca yang tidak memungkinkan sehingga pengetahuan belum tentu berpengaruh atau berhubungan dengan praktik atau perilaku seseorang.

Analisa peneliti dalam penggunaan Alat Pelindung Diri lebih kearah kesadaran seseorang atau petani itu sendiri bukan dari paksaan, karena menumbuhkan rasa kesadaran tidak akan adanya suatu kewajiban di masyarakat.

\section{Hubungan Sikap dengan Praktik Penggunaan Alat Pelindung Diri (APD)}

Hasil uji statistik menggunakan chi square dengan taraf kepercayaan 5\% $(0,05)$ didapatkan nilai $\rho$ value $=0,487(\rho$ value $<0,05)$ maka $\mathrm{H}_{0}$ diterima sehingga dapat disimpulkan bahwa tidak ada hubungan antara sikap dengan praktik penggunaan Alat Pelindung Diri (APD) pada petani pengguna pestisida di Desa Sigambir Kecamatan Brebes Kabupaten Brebes Tahun 2018.

Hasil penelitian ini sejalan dengan hasil penelitian yang dilakukan Muhammad Nur Sohib dengan judul hubungan antara pengetahuan dan sikap dengan praktik pemakaian Alat Pelindung Diri (APD) pada petani pengguna pestisida di desa Curut Kecamatan Penawangan Kabupaten Grobogan tahun 2013 yang menyatakan tidak ada hubungan antara sikap terhadap praktik pemakaian APD pada petani pengguna pestisida dengan nilai $\rho$ value $=0,902$ (Shobib, M.N., 2013).

Berbeda dengan hasil penelitian Faris Khamdani dengan judul hubungan antara pengetahuan dan sikap dengan pemakaian Alat Pelindung Diri (APD) pestisida semprot pada petani di Desa Angkatan Kidul Pati tahun 2009 yang menyatakan ada hubungan antara sikap dengan pemakaian Alat Pelindung Diri (APD) pestisida semprot pada petani dengan nilai $\rho$ value $=0,001$ (Khamdani, F., 2009).

Berdasarkan hasil penelitian yang telah dilakukan sikap petani tentang pernyataan manfaat memakai APD penutup hidung dan mulut (masker) pada saat penyemprotan pestisida sebanyak $69,7 \%$ petani menjawab setuju. Pada praktiknya petani yang selalu menggunakan masker hanya $48,7 \%$, angka ini menunjukkan bahwa sikap belum dapat mengubah praktik petani untuk selalu menggunakan masker saat berinteraksi dengan pestisida. Masker akan melindungi hidung dan mulut karena salah satu jalan masuknya pestisida adalah melalui pernafasan, pestisida akan ikut masuk melalui hidung maupun mulut. Kenyataan bahwa kurangnya praktik penggunaan masker masih sangat minim, oleh karena itu perlu untuk meningkatkan sikap pemakaian 
masker dengan cara diadakan penyuluhan tentang pentingnya penggunaan APD khususnya penggunaan dan penutup hidung dan mulut (masker).

Sikap petani tentang pernyataan sepatu boot harus digunakan saat berinteraksi dengan pestisida sebesar 10,5\% petani menjawab setuju bahwa sepatu boot merupakan alat pelindung diri yang penting untuk dikenakan saat melakukan penyemprotan pestisida. Dalam praktiknya petani yang memakai sepatu boot saat penyemprotan hanya sebesar 2,6\%, sikap yang negatif menjadi salah satu faktor petani tidak menggunakan sepatu boot, selain itu faktor wilayah juga mempengaruhi petani sulit berjalan di area yang berlumpur sehingga akan sulit jika menggunakan sepatu boot. Oleh karena itu perlu untuk meningkatkan praktik penggunaan sepatu boot dengan cara sosialisasi yang dilakukan pada saat perkumpulan kelompok tani, disamping itu pemilihan sepatu boot juga berpengaruh terhadap praktik pemakaian saat bekerja.

Sikap merupakan predisposisi untuk melakukan atau tidak melakukan suatu perilaku tertentu, sikap lebih suatu proses kesadaran yang sifatnya

Individual (Notoatmodjo S., 2010). Suatu sikap belum otomatis terwujud dalam suatu tindakan. Untuk terwujudnya sikap agar menjadi tindakan yang nyata diperlukan komponen apa saja yang mempengaruhi sebuah sikap seseorang. Tindakan seseorang terhadap stimulus tertentu akan banyak ditentukan oleh bagimana kepercayaan dan perasaannya terhadap stimulus tersebut. Secara biologis, sikap dapat dicerminkan dalam suatu bentuk tindakan, namun tidak pula dapat dikatakan bahwa sikap dan tindakan memiliki hubungan yang sistematis (Notoatmodjo S., 2012).

Tidak adanya hubungan antara sikap dengan praktik penggunaan Alat Pelindung Diri (APD) dikarenakan ketidakyakinan responden akan adanya Alat Pelindung Diri (APD) yang dapat melindungi kita dari kecelakaan kerja atau bahaya yang ditimbulkan oleh pertisida.

\section{KESIMPULAN}

Dari 76 responden yang diteliti sebanyak 51,3\% responden memiliki pengetahuan kurang baik tentang Alat Pelindung Diri (APD), 51,3\% responden memiliki sikap negatif dan 98,7\% responden tidak lengkap dalam penggunaan Alat Pelindung Diri (APD). Tidak ada hubungan antara pengetahuan dengan praktik penggunaan Alat Pelindung Diri (APD) pada petani pengguna pestisida di Desa Sigambir Kecamatan Brebes Kabupaten Brebes tahun 2018. Tidak ada hubungan antara sikap dengan praktik penggunaan Alat Pelindung Diri (APD) pada petani pengguna pestisida di Desa Sigambir Kecamatan Brebes Kabupaten Brebes tahun 2018.

\section{DAFTAR PUSTAKA}

Cahyono A.B..2004. Keselamatan Kerja Bahan Kimia Industri, Yogyakarta; Gadjah Mada University Press

Khamdani, F. 2009. Hubungan Antara Pengetahuan dan Sikap dengan Pemakaian Alat Pelindung Diri Pestisida Semprot pada Petani di Desa Angkatan Kidul Pati Tahun 2009. Skripsi. Semarang: Fakultas Ilmu Keolahragaan Universitas Negeri Semarang

Notoatmodjo S. 2010. Promosi Kesehatan Teori dan Aplikasi. Jakarta;; PT RINEKA CIPTA

Notoatmodjo S.2012. Pendidikan dan Perilaku Kesehatan, Jakarta: Rineka Cipta

Notoatmodjo S.2014. Metodologi Penelitian Kesehatan. Jakarta: RINEKA CIPTA 
Saputro V.A. 2015. Hubungan Antara Pengentahuan dan Sikap dengan Pengguna Alat Pelindung Diri (APD) pada Pekerja di Unit Kerja Produksi Pengecoran Logam : 810.

Shobib, M.N. 2013. Hubungan Antara Pengetahuan dan Sikap dengan Praktik Pemakaian Alat Pelindung Diri (APD) Pada Petani Pengguna Pestisida di Desa Curut Kecamatan Penawangan Kabupaten Grobogan, : 1-5

Soedirman, Suma'mur PK. 2014. Kesehatan Kerja Dalam Perspektif Hiperkes dan Keselamatan Kerja, Jakarta: Erlangga.

Anonim $^{1}$, 2018, Universitas indonesia. Industrial Chemical Hygiene, Safety, and Security. http://k31.ui.ac.id/industrial-chemical-hygiene-safety-and-security diakses 24 mei 2018.

Anonim $^{2}$, 2018, Kabuptaen Brebes; [diunduh tanggal 24 Mei 2018]. Tersedia dari: https://id.wikipedia.org/wiki/Kabupaten_Brebes

Anonim $^{3}$, 2013, Uji Chi-Square; [diunduh tanggal 6 Juni 2018]. Tersedia dari: https://elearningti3605.wordpress.com/2013/12/26/uji-chi-square/

Purwati A., 2010, Pestisida Ganggu Kesehatan Petani; [diunduh tanggal 28 April 2018]. Tersedia dari: www.beritabumi.or.id. 